\title{
Al-Quran Wal-Hifz's Heterogeneity of Teaching Methods among Dini Integrated Curriculum Sharia Teachers
}

\author{
Firdaus Abdul Fatah, Khadijah Abdul Razak, Maimun Aqsha Lubis, Noor Azimah Surip \\ Centre of Education and Community Wellbeing, Faculty of Education, Universiti Kebangsaan Malaysia, Selangor, Malaysia \\ Email:khadijah.razak@ukm.edu.my
}

How to cite this paper: Fatah, F. A., Razak, K. A., Lubis, M. A., \& Surip, N. A. (2019). Al-Quran Wal-Hifz's Heterogeneity of Teaching Methods among Dini Integrated Curriculum Sharia Teachers. Creative Education, 10, 2584-2592. https://doi.org/10.4236/ce.2019.1012186

Received: October 16, 2019

Accepted: November 24, 2019

Published: November 27, 2019

Copyright $\odot 2019$ by author(s) and Scientific Research Publishing Inc. This work is licensed under the Creative Commons Attribution International License (CC BY 4.0).

http://creativecommons.org/licenses/by/4.0/

\begin{abstract}
The Al-Quran Wal-Hifz is one of the sections in Sharia subjects that employ the Dini Integrated Curriculum. This field calls for students to memorize several verses with the sentence meaning and the whole meaning of the surah. The objective of this research is to examine the methodology employed by teachers to fulfill this goal. The design of this study is a qualitative study comprising interviews with eight teachers who teach Sharia subjects in Government Facilitated Religious Schools (SABK) as primary sources, eight students together with the observation of teacher teaching as a source of support. The findings prove that teachers are positive and have about six teaching methods when teaching the Al-Quran Wal-Hifz such as singing, finger movement and hand gestures. Hence, this research is intended to be a guide for other teachers to be creative in their teaching.
\end{abstract}

\section{Keywords}

Al-Quran Wal-Hifz, Memorize, Dini Integrated Curriculum, Teaching Methods

\section{Introduction}

Government Facilitated Religious schools are one of the largest religious schools in Malaysia. The school is comprised of State Religious Schools, and People's Religious Schools registered with the Ministry of Education (MOE) and has established a Memorandum of Understanding ( $\mathrm{MoU}$ ) to be co-managed between the MOE and the School Management Board (LPS) (Shamsul Shah, 2013).

Since 2005, the government founded a new curriculum to be assimilated in all Government Facilitated Religious Schools (SABK) known as the Dini Integrated 
Curriculum (KBD). This curriculum has grown into a national curriculum. This curriculum is a coordination of the Azhari curriculum among other uncoordinated disparate states previously (KPM, 2015).

The subjects presented in this curriculum are al-Lughatul Arabiyyah Al-Mu'asiroh, Al-Syariah, Usul al-Din, Manahij Al-Ulum al-Islamiah dan al-Adab wa al-Balaghah. The Al-Quran Wal-Hifz is one of the areas in the subject of Sharia. Other areas of interest incorporate are Fiqh-Ibadat, Fiqh Munakahat, Fiqh al-Muamalat dan Fiqh al-Jinayat (KPM, 2015). Even though Al-Quran Wal-Hifz field may seem a little awkward to be categorized with Sharia subjects, it adheres with the objective of the Shariah curriculum, to foster knowledgeable, believing, righteous, noble attitude, charismatic based on Quran and al-Sunnah.

The aim between the field of figh and the field of the Al-Quran Wal-Hifz is proposed in the Curriculum Standard Documents. Al-Quran Wal-Hifz field intends to read, memorize and comprehend the definition of the verses from the chosen Quranic verses correctly, fluently, righteously and fluently while the field of figh is more about formulating comprehension of relevant matters and implementing it in life.

\section{Problem Statement}

The execution of the Primary School Curriculum (KSSR) in 2011 indicates the starting point of the transformation of education in Malaysia (Ministry of Education, 2006).

Afterwards, an education plan was formulated, the Malaysian Education Development Plan 2013-2025 (2013). The plan also highlights the seriousness of critical and creative thinking that: "every child will learn how to pursue to acquire knowledge throughout their lives (fostering a love for investigation and lifelong learning), assimilating disparate knowledge, and designing new knowledge. Every child will master a diversity of critical cognitive skills, comprising critical thinking, reasoning, creative thinking and innovation" (Malaysian Education Development Plan 2013-2025, 2013). As the consequence of the development of this curriculum, teachers have been demanded to employ teaching that stresses creative and critical thinking, as well as high order thinking skills, accentuated in Malaysian schools (Peng \& Nadarajan, 2014; Syed, Mohd, \& Julismah, 2017).

However, the approach of teachers who teach religious subjects related explicitly with the Al-Quran Wal-Hifz is usually regarded as being not creative. Muhamad Suhaimi (2011) proposed that teachers were found to be less focus on the components of creativity in their teaching process, hence revealing flaws in the delivery of teacher teaching in the classroom. The situation exhibits that teachers who teach in the field of Religion are less capable of responding to the recommendation of the Malaysian Ministry of Education who want to produce students who can implement knowledge and think critically in non-academic contexts. 
Other than the context of Al-Quran Wal-Hifz found some shortcomings among the tahfiz students while memorizing the Quran. Students were observed to be concentrating on disparate sentences rather than trying to find the definition of the sentence and the meaning of the sentence. In this regard, teachers are less concerned with the prominence of comprehending the verse, but students are trying to understand the verse just to make it easier for them to memorize (Azmil \& Ab Halim, 2012; Azmil, Ab Halim, Misnan, \& Mohd Aderi, 2014).

Thus, this study was completed to recognize the varying teaching methods exploited by the Sharia teachers in the SABK during Al-Quran Wal-Hifz teaching and learning process which facilitates students memorize the meanings of words from the 30th chapter and memorize a few chapters along with the meanings.

\section{Literature Review}

The Quran is a revelation of Allah that guides all Muslims. It was passed down to Prophet Muhammad through the Prophet Jibril as a guide to all. The Quran is too, a miracle to the Prophet Muhammad (SAW) who is preserved until hereafter. As maintained by, Mohd Aderi, Amjad, Othman, \& Asmawati (2013), the Prophet Muhammad has left behind a model of Quranic teaching that is through reading repetition. The repetition of these readings comprised of five stages, specifically bin-nazar (the process of reading the verses of the Qur'an carefully and repeatedly while looking at the Quran), tahfiz (memorizing and reciting verses without any mistakes), Talaqqi (reading while others are listening), Takrir (repetition of the verse at any time so that one does not forget) and the last is tasmik (listening to good, accurate and fluent memorization) (Siti Suriyani, 2018).

Al-Hifz means to memorize something. Ergo, to fulfill this goal, in teaching and learning, a diversification of organized and systematic techniques and systems have been exploited in the institution of memorizing the Quran. Fundamentally, the process of memorizing Quranic verses requires the repetition of memorized verses. Moreover, it requires ongoing commitment and systematic preparation as per the research of Mustafa \& Basri (2014). They revealed that the process of repeating the verses of the Quran to memorize can be implemented through a five-time prayer and daily zikr.

Meanwhile, Saidah, Muhammad Lukman, Mustapha, \& Mustapha Kamal (2015) study presented that standard four students have succeeded in developing their level of achievement after teachers exercised the game method to students during several verses memorization in a typical verse. The concept of Learning While Playing is an activity that can promote students' passion for learning. Games that are contests or matches along with specific rules will make teaching and learning sessions fun in a fun environment (Mamat \& Ismail, 2010).

Ibn Khaldūn recommends two leading suggestions that the education system should pay close attention to, particularly knowledge or co-curriculum and student-centred methods and measures (Gamal, 2003). Following this, have im- 
plied that teachers should plan their teaching well and choose methods that are appropriate to present developments to appreciate student skills. This is matched with the discovery of Sharifah Norshah, Mohd Shafiee, Tasnim, Kasimah, Nik Azeah (2018), who found the impression that our society today values and emphasizes Quranic learning since the development of various methods of contemporary Quranic teaching is readily available.

\section{Research Objectives}

The ground of this study is to point out the teaching method of Al-Quran Wal-Hifz utilized among the Sharia teachers in the SABK.

\section{Research Methodology}

\subsection{Research Design}

This study adopts a qualitative approach. The decision to employ this approach is in line with Creswell's (2007) assertion that this method is relevant to implement in research questions that call for answers on how and what is happening and interpreting something different from common understanding. The research of the approach acquired is from the perspective of the study respondents and not from the researcher. The design of this study is to exploit the case study method. The researcher selects this method in line to study and describe a small group thoroughly. As claimed by Yin (2002), the case study method, which is suitable for the goal of the study, was picked as it aims to study the phenomena that occur in the actual context. To get comprehensive data to answer the research questions, the researcher used data collection interview techniques with teachers, student, and teacher teaching observations. The analysis of these data will allow the researcher to detail on the teaching method used by the teacher.

\subsection{Data Analysis}

The interview data secured will be transcribed exploiting NVivo software version 12. The data were analyzed inductively. Then, the data analyzed will be compared with the constant comparative method (Yin, 2002) to produce themes that arise from the research questions. Consequently, the interview data will be triangulated by observation and document analysis to obtain internal validity and reliability.

\section{Findings}

The findings of the first question are proven that the study participants employed heterogeneity of teaching methods. The first method is Talaqqi and $\mathrm{Mu}$ syafahah. This method is implemented by the teacher to ensure that the reading of the students is correct in terms of makhraj and also the rules contained in the verse. Study participant 5 stresses the need for this method to identify students' reading comprehension before they could memorize the entire verse in the chapter. This statement is elaborated in his words; "When it comes to Quran 
(reading), I would hear they read it, one person at a time. During that period, I would be able to see if s/ he was read it right or not. I can spot which students who are weak and who read well." (TBU/PK4/TB1)

While PK1 too admits the weight of this method is to ensure that students are reading correctly and accurately; "While the kids are trying to memorize the verses, they have to consider the rules of tajwid too." (TBU/PK1/TB1)

On top of that, the attention on proper reading is evident in the words of the students: When it comes to taste, we like it. "Ustazah (Female religious teacher) always asks us to read the Qur' an with the correct meaning of the word because when we read the verse correctly, we enjoy reading it. Accordingly, we will like it. When we read it, we can memorize it. (TBS/TBS/PK2)

Successive teachers implement the Tasmik method after the Musafahah talaqqi method. Once students have been able to read accurately through talaqqi and musafahah, the study participants will use the Tasmik method to listen to different students. As for $\mathrm{Pk} 8$, s/he will perform tasmik in class. $\mathrm{He}$ offered rewards to students as mentioned; "When it comes to memorizing, ( $I$ will do it) as usual. Everyone stands up. Anyone who has memorized can sit down." (TBU/PK8/TB1)

Nevertheless, for PK1, he did not limit tasmik in class. He described the situation as being more favorable by the students as they can conduct tasmik when being fully prepared. His statement was; "Al-Quran Wal-Hifz is not (conducted) only in the classroom, it is going on (anywhere). Occasionally, we meet at the canteen ... this is a continuos progress" (TBU/PK1/TB1). Meanwhile, PK3 adopts the Tasmik method for students in the initial part of each lesson. She was also allowed to serve as a relief teacher at the time of other subject teachers. This is evident based on his/her statement; "I will run hafazan session, taking advantage of the time. Unless the teacher leaves something to do, I will ask the students to do it first." (TBUIPK3/TB1)

The outcome of the interview with a student has validated the teacher's statement on the implementation of these rules through his words; "The teacher will have classes, one session, she will focus on the Quran solely. Moreover, then we will have tasmik sessions one by one" (TBS/TBS PK7). The triangulation of student interviews and observations of teacher teaching reflect that teachers exploit the above three methods, but in different situations.

The third method employed by PK4, PK5, and PK6 is the finger signal. This approach intends to benefit students in terms of memorization sentences swiftly. The finger signal suggested that the study participants would ask students to raise their fingers to signal the number of sentences being read. This scenario can be observed through the observations made by the study participants. They found that they would point the finger at each sentence read, and s/he asked the students to do the same when repeating the reading of the verse they were studying. The student admits the scenario of implementing this method through his/her study; "Like now, ustaz (male religious teacher) teaching a different way 
by counting by hand. In that way, it is easier to memorize (TBS/TBSPK5)."

The fourth method is singing. PK1, PK2, and PK3 use this method. The exercise of this method is not to entertain, but to help the students to remember the meaning of the selected word in the chapter or the translation of the whole verse such as the description of PK2; "Yes to know the meaning. It is not just singing. The students have to sing and perform style and play. I made it that way so that it is easier for them to memorize the song for the meaning of Qur' an." Even though all three study participants employed the singing method, the criteria for song selection were adopted to assist students easily understand the meaning of the words and verses. PK1 and PK2 were observed to allow students to choose their song according to their method while PK3 created their rhythm. S/he had his style as the affirmation; "But I cannot sing other people's songs. This is my song. So, I have to build on that expression. I cannot get rid of the Nun and Syaddah من الجن. Ha.. that I have to endure, so I cannot take away the rhythm from any of the songs, I will choose the ones that are suitable with me". (TBU/PK3/TB2). The freedom that PK1 allows on his students to compose appropriate songs to remember the meaning of words and verses is evident as follows; "Last year, we gathered standard 3 students so that we can memorize it in a group." TBS/TBSPK1

The fifth method is physical movement. The physical gestures adopted by the study participants were hand gestures and facial expressions. This method is too employed by the teacher to help students to memorize the meaning of the sentence and the complete chapter. The researchers observed this method during their teaching (OB2/PK4) and (OB2/PK5.). In their teaching, the study participants were observed to adopt hand to illustrate the meaning of the sentence for each sentence read, such as the student's description; Ustaz also described something. That verse is the verse of al-Qiamah. The meaning of the verse is something collapsing (hand gesture like fall). (TBS/TBS PK5). The description of how the study participants used face expression is understood from the following student explanations; "Make the style عبسي وتولى". There is a sad face, so it is kind of easy for us to understand. There is another way, the harakat yadawiyah (hand gestures) (TBS/TBSPK6).

The sixth method is the game. Playing methods are very famous in PK2 and PK4 Games implemented by the study participants as an active learning form as students will compete to participate in the game. PK 2 has created its own game called Hibiey, habibatiey. She will assimilate the game into her teaching session as it will allow students to participate in their learning actively. (OB1/PK2). In addition to promoting a positive competitive spirit to memorize, PK4 employed the game method to train other students. She would ask the students to form a circle and the students to throw the ball randomly to a friend. Students who are hit by the ball need to express their reading. The explanation is as follows; " $I$ practice that with students directly in the classroom. Then I throw the ball or perform tasmik" (TBU/PK4/TB2). 
The triangulation data with students in the PK2 and PK4 study proved that the adoption of the game-making method was utilized to make students eager to learn such as student statements; “... Ustazah Raihan passed ermmm a ball. So when the ball goes to one of those groups, she will ask what we have memorized. That is the most impactful with Ustazah Raihan." (TBS/TBSPK4). Additionally, PK2's student will be excited by their creativity. According to her; "There will be one game or two. Even though it's the same games, but sometimes there are different games." (TBS/TBSPK2)

\section{Discussions}

From the data presented, it is evident that the Sharia teachers at SABK cater to positive feedback on creativity by diversifying their teaching methods. Even though they still adopt the talaqqi and musyafahah methods, they try other creative ways to attract the attention of the al-Quran hafazan students and together with their translations. They even make the Al-Quran Wal-Hifz teaching and learning sessions lively and fun and relax. Hence, Sharia teachers have exercised one of the key objectives of the Malaysian Education Master Plan 2006-2010 (Ministry of Education, 2006) to produce creative human resources in Malaysia. In accordance with this (Ab Halim\& Azman, 2010), the emphasis on creativity in teaching and learning is an aspect that helps to intensify the efficiency and quality of teaching in the field of Islamic Education which can be put into practice with a variety of methods and strategies that meet the needs of students as "knowledge workers". On top of that, teachers who offer creativity in teaching reflect the competency of the teaching and learning process (Agus \& Saleh, 2009; Kassim, 2011; Yahaya \& Noor Sharliana, 2011; Rohani, Hazri, \& Mohmmad Zohir, 2017).

This discovery is also following Shulman's (1986) view that teachers with a high level of pedagogical knowledge will implement their teaching in a variety of ways such as creating analogies, metaphors, and diversifying methods and creativity to promote students' comprehension (Muzirah \& Nurhana, 2013). Even though the study participants found that they did not use teaching aids, they still managed to create a variety of sophisticated and fun teaching techniques. Teachers should also not be bound by anyone's teaching mode. Instead, they optimize their skills by always thinking outside the box of common sense to establish a new, practical approach to understanding students' achievement beyond the limits of their optimal capabilities (Naquiah \& Jimain, 2016; Abdul Rasid \& Hasmah, 2016).

\section{Implications and Future Research Suggestions}

This research can function as a guide for teachers, especially for those who teach at SABK so that they can employ a variety of active and exciting teaching approaches that encourage students to participate in their teaching and learning sessions. Also, this study fixes the portrayal of teachers and corrects the 
perception that teachers who teach the religious curriculums cannot implement 21st-century learning without mastering the field of ICT since in fact 21st-century learning practices will continue to be successful if it is student-centered and active. Not just that, this study can also serve as a guide to appropriate parties such as the Curriculum Development Division, the Islamic Education Division to formulate a continuous and regular course that furnishes guidance to teachers in SABK on the latest teaching methods.

\section{Acknowledgements}

This research was funded through the project with Faculty of Education and National University of Malaysia (UKM) Research Grant GG-2019-058 and PP-FPEND-2019.

\section{Conflicts of Interest}

The authors declare no conflicts of interest regarding the publication of this paper.

\section{References}

Abdul Rasid, J., \& Hasmah, I. (2016). Pelaksanaan pembelajaran menyeronokkan dalam pengajaran dan pembelajaran Bahasa Melayu. Jurnal Pendidikan Bahasa Melayu, 3, 49-63.

Azmil, H., \& Ab Halim, T. (2012). Persepsi pelajar terhadap kaedah pembelajaran tahfiz al-Quran di Malaysia. Journal of Islamic and Arabic Education, 4, 1-10.

Azmil, H., Ab Halim, T. A., Misnan, J., \& Aderi, C. N. (2014). Kaedah pembelajaran tahfiz dan hubungannya dengan pencapaian hafazan pelajar. Journal of al-Quran and Tarbiyyah, 1, 9-16.

Creswell, J. W. (2007). Qualitative Inquiry and Research Design: Choosing among Five. Thousand Oaks, CA: Sage.

Gamal, A. N. Z. (2003). Prinsip-prinsip Pendidikan Islam: Ibn Shanun Al-Qabisi Ibni Khaldun. Pahang: PTS Publication \& Distributors Sdn Bhd.

Kementerian Pendidikan Malaysia KPM (2015). Maklumat asas pelaksanaan Kurikulum Bersepadu Dini. Putrajaya: BPI.

Mohd Aderi, C. N., Amjad, H., Othman, G., \& Asmawati, S. (2013). The Study of Quranic Teaching and Learning. Middle East Journal of Scientific Research, 15, 1338-1344.

Muhamad Suhaimi, T. (2011). Faktor gaya pertautan dan motivasi pelajar, serta proses pengajaran dan bimbingan guru pendidikan islam terhadap pembelajaran terarah kendiri (PTK) Pelajar. Phd Thesis, Kota Kinabalu: Universiti Malaysia Sabah.

Naquiah, N., \& Jimaain, S. (2016). Amalan pengajaran Jawi dalam pendidikan masa kini: Suatu tinjauan. TAMU Journal, 2, 70-85.

Peng, C. F., \& Nadarajan, S. (2014). Implementation of Creative and Critical Thinking Skills in Teaching and Learning of Literary Component in High School. Jurnal Pendidikan Bahasa Melayu, 4, 10-24.

Rohani, A., Hazri, J., \& Mohmmad Zohir, A. (2017). Integrated Model of Infusing 21st Century Skills in Teaching and Learning. Malaysian Journal of Education, 42, 1-11. http://ejournal.ukm.my/jpend/article/view/19590 
Saidah, H. S., Muhammad Lukman, I., Mustapha, A., \& Mustapha Kamal, A. K. (2015). Kemahiran menghafaz surah melalui permainan. Jurnal Tempawan, 32, 38-48.

Shulman, L. S. (1986). Those Who Understand: Knowledge Growth in Teaching. Educational Researcher, 15, 4-14. https://doi.org/10.3102/0013189X015002004

Siti Suriyani, S. (2018). Kaedah hafazan: Suatu tinjauan ringkas. E-Journal of Islamic Thought and Understanding, 2, 44-59.

Syed Kamaruzaman, S. A., Mohd Zaki, C. H., \& Julismah, J. (2017). Efikasi kendiri guru pendidikan jasmani terhadap pelaksanaan pengajaran mata pelajaran pendidikan jasmani. JuKu: Jurnal Kurikulum \& Pengajaran Asia Pasifik, 2, 43-51.

Yahaya, B., \& Noor Sharliana, M. N (2011). Faktor-faktor yang mendorong kreativiti di kalangan pelajar, Universiti Teknologi Malaysia. Journal of Educational Psychology and Counseling, 2, 175-208.

Yin, R. (2002). Case Study Research: Design and Methods (3rd ed.). Thousand Oaks, CA: Sage Publications. 